\title{
Dipodidae (Mammalia, Rodentia) from the Paleogene of south-east Serbia
}

\author{
Wilma Wessels $^{1}$ (D) Andrew A. van de Weerd ${ }^{1}$ (D) $\cdot$ Hans de Bruijn $^{1} \cdot$ Zoran Marković $^{2}$
}

Received: 6 September 2018 / Revised: 20 December 2018 / Accepted: 11 June 2019 / Published online: 28 October 2019

(C) The Author(s) 2019

\begin{abstract}
Isolated cheek teeth of the Asian dipodid Heosminthus primiveris from four early Oligocene localities in the Koritnica-Babušnica basin, south-east Serbia, are described. The record of the Paleogene Dipodidae of Central Asia and Europe is briefly discussed. The current view of the migration pattern of the Paleogene Dipodidae between central Asia and Europe is revised: the migration of Plesiosminthus into Europe during the late Oligocene was preceded by the immigration of Heosminthus into the SerboMacedonian high (S. E. Europe) during the early Oligocene.
\end{abstract}

Keywords Eocene $\cdot$ Early Oligocene $\cdot$ Rodentia $\cdot$ Dipodidae $\cdot$ South-east Serbia

\section{Introduction}

${ }^{1}$ The Dipodidae described in this paper are part of the late Eocene-early Oligocene small mammal assemblages found in south-east Serbia. The geological setting and composition of these faunas (consisting mainly of rodents) have been described by de Bruijn et al. (2018). Three rodent groups have been studied and papers are online and printed: the Diatomyidae (Marković et al. 2018), the Melissiodontinae (Wessels et al. 2018) and the Paracricetodontinae (van de Weerd et al. 2018), while publications on the Pappocricetodontinae are online (de Bruijn et al. in press) and the Pseudoricetodontinae are in

\footnotetext{
${ }^{1}$ This is the seventh paper in the series: "The Paleogene rodent faunas from south-east Serbia".

Wilma Wessels

w.wessels@uu.nl

Andrew A. van de Weerd

a.vandeweerd@uu.nl

Hans de Bruijn

HdBruijn@uu.nl

Zoran Marković

zoran.markovic@nhmbeo.rs

1 Department of Earth Sciences, Utrecht University, Princetonlaan 8A, 3584 CB, P.O. Box 80021, 3508 TA Utrecht, The Netherlands

2 Natural History Museum in Belgrade, Njegoševa 51, Belgrade 11000, Serbia
}

preparation (Marković et al. in press). Table 1 shows the distribution of rodent species in these faunas. One new site, RaljinB, was sampled in 2017 and in 2018; it is included in Table 1. The site is at the same location as Raljin, but stratigraphically about $2 \mathrm{~m}$ higher.

The extant Dipodidae Fischer, 1817 occupy a diverse array of ecological niches and consequently shows a wide range of morphological adaptations. The fossil record of the family suggests that the family originated in Asia during the early Eocene and that the radiation that leads to the present day diversity occurred during the Oligocene. Pisano et al. (2015) reconstructed phylogenetic relationships of the family based on molecular evidence. As far as we are aware none of the extant genera can be traced to its Eocene ancestor (Lopatin 1999, 2004; Lopatin and Zazhigin 2000).

The history of the Dipodidae in Asia is very different from that in Europe, so a concise overview of the Paleogene record in these two areas is considered appropriate. Until recently, the oldest record of the Dipodidae in central and south western Europe was Plesiosminthus promyarion Schaub, 1930, localities of the early part of the late Oligocene: Puy-de-Mondoury (France) and Rickenbach (Germany) both in MP 28/29. Hugueney and Vianey-Liaud (1980) redefined Schaub's poorly documented species on the basis of a rich sample from Pech Desse (France; MP27/28). Freudenthal and Martín-Suárez (2017) reviewed European Plesiosminthus populations and suggested to restrict the species name Plesiosminthus promyarion Schaub, 1930, to its poor-type material and 
Table 1 Distribution of species in the rodent assemblages from south-east Serbia

\begin{tabular}{|c|c|c|c|c|c|c|c|c|c|c|c|}
\hline \multirow[b]{2}{*}{ Family } & \multirow[b]{2}{*}{ Subfamily } & \multirow[b]{2}{*}{ Genus and species } & \multicolumn{2}{|l|}{ Eocene } & \multicolumn{6}{|c|}{ Early Oligocene } & \multirow[b]{2}{*}{$\begin{array}{l}\text { TotalM1- } \\
\text { M2-m1-m2 }\end{array}$} \\
\hline & & & Zvonce & Buštranje & $\begin{array}{l}\text { Strelac- } \\
1\end{array}$ & $\begin{array}{l}\text { Strelac- } \\
2\end{array}$ & $\begin{array}{l}\text { Strelac- } \\
3\end{array}$ & Valniš & Raljin & $\begin{array}{l}\text { Raljin- } \\
\text { B }\end{array}$ & \\
\hline Diatomyidae & Diatomyinae & Inopinatia balkanica & & & 7 & 4 & 3 & 49 & 2 & 23 & 88 \\
\hline Dipodidae & Primordial Zapodidae & $\begin{array}{l}\text { Heosminthus } \\
\text { primiveris }\end{array}$ & & & & $\mathrm{X}$ & 22 & 21 & 2 & 26 & 71 \\
\hline \multirow[t]{18}{*}{ Muridae } & Cricetodontinae & cf. Deperetomys sp. & & & & & & & 1 & & 1 \\
\hline & Pseudocricetodontinae & $\begin{array}{l}\text { Heterocricetodon } \\
\text { serbicus }\end{array}$ & & & 13 & 7 & 7 & 49 & 5 & 29 & 110 \\
\hline & & $\begin{array}{l}\text { Pseudocricetodon } \\
\quad \text { heissigi }\end{array}$ & & & & & 12 & & & & 12 \\
\hline & & $\begin{array}{l}\text { Pseudocricetodon cf. } \\
\quad \text { heissigi }\end{array}$ & & 27 & & & & 28 & 7 & 19 & 81 \\
\hline & & $\begin{array}{l}\text { Pseudocricetodon } \mathrm{cf} \\
\text { montalbanensis }\end{array}$ & & & 4 & & 12 & & & 51 & 67 \\
\hline & Paracricetodontinae & Paracricetodon dehmi & & & 3 & & $\mathrm{X}$ & 10 & & 3 & 16 \\
\hline & & $\begin{array}{l}\text { Paracricetodon } \\
\text { gracilis }\end{array}$ & & & & & 2 & 11 & $?$ & $\mathrm{X}$ & 13 \\
\hline & & $\begin{array}{l}\text { Paracricetodon } \\
\text { stojanovici }\end{array}$ & & 75 & 45 & 26 & 30 & 127 & 9 & 42 & 354 \\
\hline & Pappocricetodontinae & Witenia cf. flava & & & 5 & & $\mathrm{X}$ & 2 & & 4 & 11 \\
\hline & & Witenia europea & & 21 & & & & & & & 21 \\
\hline & & Bustrania dissimile & & 601 & & & & & & & 601 \\
\hline & Melissiodontinae & cf. Edirnella sp. 2 & & & 6 & 1 & & & & & 7 \\
\hline & & Mogilia sp. & & & & & & & & 1 & 1 \\
\hline & & Mogilia lautus & & & $\mathrm{X}$ & & & 34 & 1 & 17 & 52 \\
\hline & & Mogilia miloshi & 28 & 30 & & & & & & & 58 \\
\hline & & cf. Edirnella sp. 1 & & 4 & & 1 & & & & 3 & 8 \\
\hline & & cf. Edirnella sp. indet. & $\mathrm{X}$ & & & & & & & & 0 \\
\hline & ?Spalacinae & nov. gen.1 sp. A & 3 & & & & & & & & 3 \\
\hline \multicolumn{3}{|c|}{ Total number of upper and lower M1 and M2 in each locality } & 31 & 758 & 83 & 39 & 88 & 331 & 27 & 218 & 1575 \\
\hline
\end{tabular}

defined the species $P$. moniqueae on the material from the locality Pech Desse. In the same publication, these authors described the now oldest European Plesiosminthus margaritae from Mirambueno 1 (Spain; MP27 = earliest part of the late Oligocene). The Dipodidae never became diverse in Europe, remained usually rare in late Oligocene-early Miocene assemblages and went temporarily extinct during the middle Miocene. So far all the Paleogene material from Europe has been allocated to the genus Plesiosminthus. Eleven species have been formally named in south western and central Europe, but Freudenthal and Martín-Suárez (2017) did not observe clear trends in dental morphology and size to allow recognition of lineages within the European material.

In contrast to their history in Europe the Asian record of the Dipodidae goes back to the middle Eocene where the family became diverse and played a dominating role in Oligocene rodent communities (Dawson 2003; Daxner-Höck et al. 2014).

The best character to distinguish Dipodidae from Muridae is the P4, present in the Dipodidae, absent in the Muridae.
Only the murid Pappocricetodon antiquus has retained the P4 (Wang and Dawson 1994). The distinguishing character presence or absence of a neuro-vascular canal at the base of the infraorbital foramen (Gomes Rodrigues et al. 2011) is unfortunately rarely found in fossil material. Since some of the Paleogene species i.e. Palasiomys conulus Tong, 1997, are not represented by skull material, their family attribution remains uncertain. The Asian Paleogene Dipodidae have been allocated to about thirteen genera on the basis of, what in a number of cases seem to be, rather subtle differences.

The genera of Paleogene Eurasian Dipodidae currently recognised are as follows:

Plesiosminthus Viret, 1926

Heterosminthus Schaub, 1930

Parasminthus Bohlin, 1946

Heosminthus Wang, 1985

Allosminthus Wang, 1985

Sinosminthus Wang, 1985

Shamosminthus Huang, 1992 
Gobisminthus Huang, 1992

Primisminthus Tong, 1997

Banyuesminthus Tong, 1997

Bohlinosminthus Lopatin, 1999

Litodonomys Wang and Qiu, 2000

Onjosminthus Daxner-Höck, Badamgarav and Maridet, 2014

The genus Xenosminthus Lopatin and Zazhigin, 2000, has been considered to possibly be a junior synonym of Litodonomys (Daxner-Höck et al. 2014). Some of the genera listed above, such as Plesiosminthus, Parasminthus, Heterosminthus and Litodonomys have characteristic dental features, but others, such as Heosminthus and Bohlino- sminthus are based on subtle differences, such as size, presence/absence of a double metalophule in the M1, M2, length of the mesoloph(id), number of roots of the M1 and M2. Features that are known to show considerable intra-specific variation in Muridae and therefore we should hesitate to use these to distinguish genera. We therefore suspect that the Asian primordial Dipodidae are over-split on the generic level.

As a result, the surprising presence of isolated cheek teeth showing the pattern shared by all primordial representatives of the family in our early Oligocene assemblages presented an identification problem. Since a revision of the Asian Paleogene Dipodidae is far beyond the scope of this study, our allocation of this material to Heosminthus is not based on characters that are specific for that genus, but rather on the striking similarity of the Serbian teeth and the (pictures) of the type material of the genotype Heosminthus primiveris Wang, 1985, from the early Oligocene (possibly late Eocene) Caijiachong Formation, Yunnan, China.

\section{Methods}

The material studied has been collected by wet screening on a set of stable sieves in the field. Concentrates have been sorted to the 0.65 $\mathrm{mm}$ fraction under a microscope. The material described below will be housed in the Natural History Museum in Belgrade. The locality codes and abbreviations used for of the localities are as follows: 025 for Strelac-2 (STR2), 026 for Strelac-3 (STR3), 027 for Valniš (VA), 028 for Raljin (RA) and 041 for Raljin B (RA-B). A representative set of casts is kept in the comparative collection of the Department of Earth Sciences, Utrecht University. Length and width of the teeth were measured with a Leitz Ortholux microscope with mechanical stage and measuring clocks. The measurements are given in $1 \mathrm{~mm}$ units. The terminology used for parts of the cheek teeth follows Daxner-Höck et al. (2014), except for the protoloph $=$ protolophule, metaloph $=$ metalophule, metalophid $=$ metalophulid and hypolophid = hypolophulid. Capital letters are used for upper teeth, lower case for lower teeth. All figured specimens are shown as from the left side, if the original is from the right side the character on the plates has been underlined.

\section{Systematic palaeontology}

Heosminthus Wang, 1985

Type species: Heosminthus primiveris Wang, 1985

Locality: Caijiachong Formation, Yunnan, China

Type level: Early Oligocene (Wang 1985) but possibly late Eocene (see Li et al. 2016a, b)

Included species

Heosminthus borrae Daxner-Höck, Badamgarav and Maridet, 2014

Heosminthus nomogenesis Li, Gong and Wang, 2016

Remark: The well-described Oligocene faunas from the Valley of Lakes (Mongolia) have yielded two Heosminthus species $H$. borrae and $H$. chimidae (Daxner-Höck et al. 2014); H. primiveris and H. nomogenensis have been described from the late Eocene of China.

Heosminthus borrae is characterised by molars with high lophs/lophids and narrow deep valleys in between; $H$. chimidae is characterised by relatively low lophs/lophids relative to cusps and wide valleys. Another small dipodid species from the Oligocene of the Valley of Lakes that is close to $H$. chimidae in morphology was included by Daxner-Höck et al. (2014) in Bohlinosminthus parvulus. The size of Heosminthus primiveris, $H$. nomogenesis and B. parvulus is more or less the same, $H$. chimidae is distinctly larger but partly overlapping.

We have neither seen the Chinese, nor the Mongolian material; but judging by the figures and the descriptions in Wang (1985), Daxner-Höck et al. (2014) and Li et al. (2016a, 2016b) the dental characteristics of Heosminthus primiveris, $H$. nomogenesis and B. parvulus overlap and may, if more material of these species will become available, appear to be indistinguishable.

Heosminthus primiveris Wang, 1985

(Figs. 1 and 2)

Synonymy: Heosminthus specimens from Valniš, Strelac-2, Strelac-3 and Raljin identified in de Bruijn et al. (2018) as H. borrae Daxner-Höck et al. (2014).

Material and measurements: Valniš, Strelac-2, Strelac-3, Raljin and Raljin-B: see Tables 2 and 3. VA 301-360; STR2 145; STR3 111-165; RA 12,15; RA-B 1101-1140.

\section{Description}

The upper incisor is not known, but, since there is not a single incisor fragment in the collection that shows a 

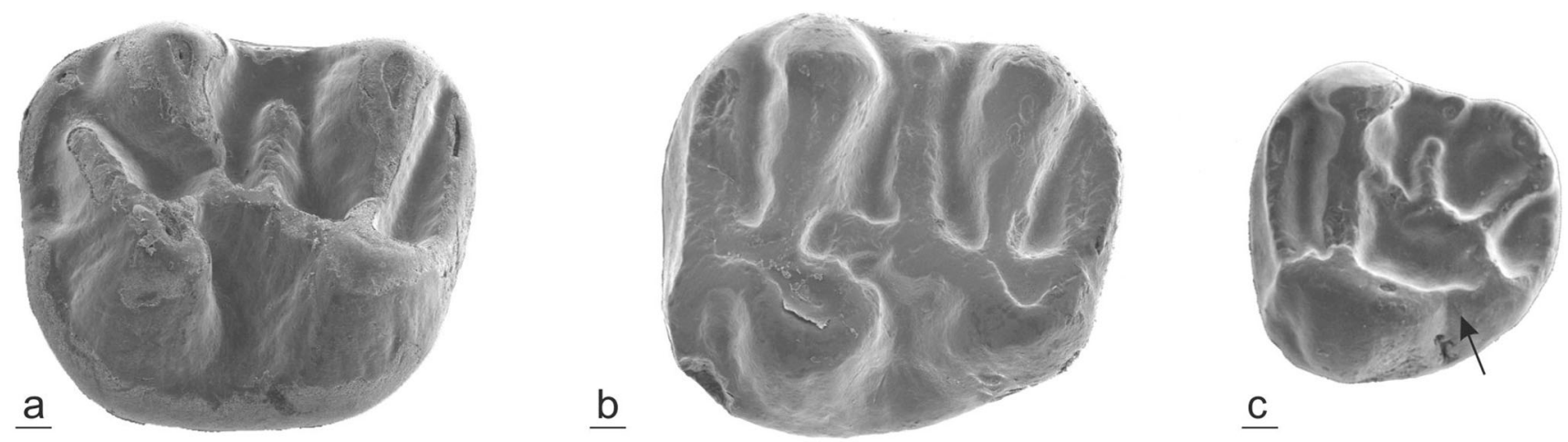

$\underline{\mathrm{C}}$
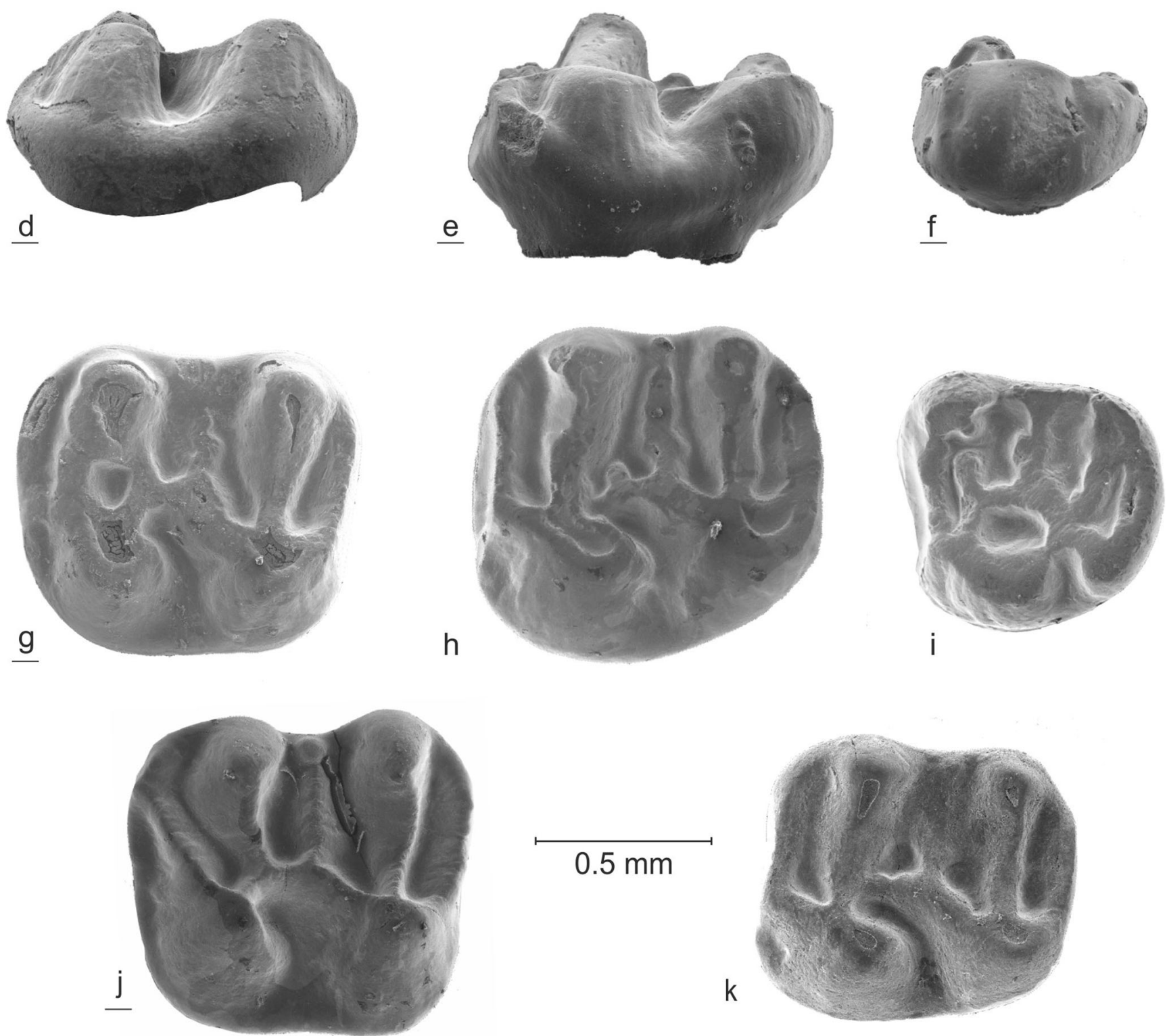

Fig. 1 Occlusal and lingual view upper molars Heosminthus primiveris from Valniš (VA) and Strelac-3 (STR3): a, d M1 dex VA-306; b, e M2 dex STR3-127; c, f M3 dex VA-326; g M1 dex VA-308; h M2 sin STR3-123; i M3 sin STR3-135; j M1 dex STR3-117; k M2 sin STR3-121 

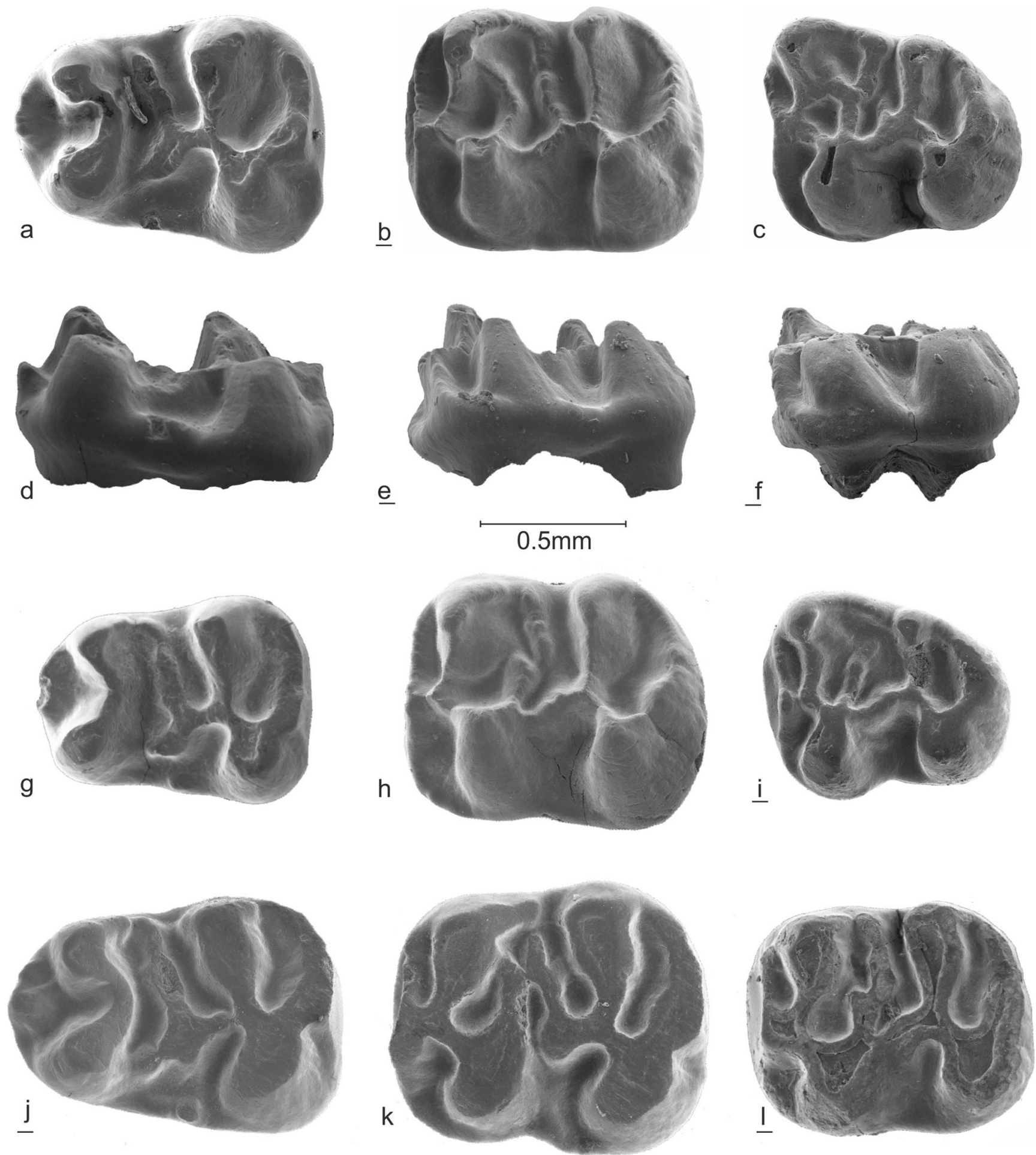

Fig. 2 Occlusal and lingual view lower molars Heosminthus primiveris from Valniš (VA) and Strelac-3 (STR3): a, d m1 $\sin$ VA-336, b, e m2 dex VA347; c, f m3 sin VA-354; $\mathbf{g}$ m1 sin VA-332; h m2 sin VA-342; i m3 dex STR3-165; j m1 dex STR3-145; $\mathbf{k}$ m2 sin, STR3-158; l m2 dex STR3-151

sulcus, it seems safe to assume that the anterior face of the upper incisor is flat.

P4: This premolar with a single root is known from Raljin-B. It shows in three of the four specimens a single cusp with a short low ridge, the remnant of the cingulum. One specimen has a single cusp without a ridge or cingulum. The P4 figured Daxner-Höck et al. (2014) of Heosminthus borrae and H. chimidae have a well-developed almost circular cingulum. M1: The weak and low anterior cingulum is interrupted in some M1 and may merge with the long and much higher 
Table 2 Measurements of cheek teeth of Heosminthus primiverus from Valniš, Raljin-B and Raljin

\begin{tabular}{|c|c|c|c|c|c|c|}
\hline & \multicolumn{3}{|c|}{ Length (mm) } & \multicolumn{3}{|c|}{ Width (mm) } \\
\hline & Range & Mean & $\mathbf{N}$ & Range & Mean & $\mathbf{N}$ \\
\hline \multicolumn{7}{|c|}{ Valnišs } \\
\hline M1 & $0.91-0.99$ & 0.96 & 7 & 0.83 & $0.80-0.87$ & 7 \\
\hline M2 & - & 0.81 & 1 & - & 0.76 & 1 \\
\hline M3 & - & 0.63 & 1 & - & 0.65 & 1 \\
\hline $\mathrm{m} 1$ & $0.87-1.07$ & 0.98 & 7 & 0.72 & $0.63-0.77$ & 7 \\
\hline $\mathrm{m} 2$ & $0.90-0.99$ & 0.95 & 6 & 0.76 & $0.73-0.82$ & 5 \\
\hline $\mathrm{m} 3$ & $0.74-0.89$ & 0.83 & 5 & 0.71 & $0.65-0.75$ & 5 \\
\hline \multicolumn{7}{|c|}{ Raljin-B } \\
\hline P4 & $0.49-0.79$ & 0.65 & 4 & 0.54 & $0.46-0.72$ & 4 \\
\hline M1 & $0.97-1.05$ & 1.01 & 6 & 0.89 & $0.83-0.94$ & 6 \\
\hline M2 & $0.85-0.99$ & 0.90 & 6 & 0.83 & $0.75-0.88$ & 6 \\
\hline M3 & $0.72-0.78$ & 0.75 & 2 & 0.77 & $0.76-0.77$ & 2 \\
\hline $\mathrm{m} 1$ & $0.96-1.03$ & 1.01 & 9 & 0.72 & $0.65-0.76$ & 9 \\
\hline $\mathrm{m} 2$ & $0.95-1.04$ & 1.00 & 5 & 0.78 & $0.69-0.85$ & 6 \\
\hline $\mathrm{m} 3$ & $0.78-0.85$ & 0.82 & 4 & 0.70 & $0.64-0.74$ & 4 \\
\hline \multicolumn{7}{|c|}{ Raljin } \\
\hline M1 & - & 0.97 & 1 & 0.88 & - & 1 \\
\hline $\mathrm{m} 2$ & - & 1.04 & 1 & 0.76 & - & 1 \\
\hline
\end{tabular}

anterior arm of the protocone. The short transverse posterior protolophule inserts on the protocone or slightly behind that cusp. One specimen from Valniš has an anterior protolophule as well as a posterior protolophule (Fig. $1 \mathrm{~g}$ ), in all other M1 there is the posterior protolophule only. The mesoloph is of medium length in five out of the seven specimens from Valniš, and in two of the six specimens in Raljin-B, but in all five M1 from Strelac 3 the mesoloph reaches the labial edge of the occlusal surface. The metalophule is transverse and inserts on the hypocone. The posteroloph is long. A small mesostyl is present

Table 3 Measurements of cheek teeth of Heosminthus primiverus from Strelac-3 and Strelac-2

\begin{tabular}{|c|c|c|c|c|c|c|}
\hline & \multicolumn{3}{|c|}{ Length (mm) } & \multicolumn{3}{|c|}{ Width (mm) } \\
\hline & Range & Mean & $\mathbf{N}$ & Range & Mean & $\mathbf{N}$ \\
\hline \multicolumn{7}{|c|}{ Strelac-3 } \\
\hline M1 & $0.91-1.00$ & 0.95 & 5 & $0.80-0.90$ & 0.86 & 5 \\
\hline M2 & $0.87-0.96$ & 0.91 & 9 & $0.80-0.89$ & 0.85 & 8 \\
\hline M3 & $0.70-0.75$ & 0.73 & 2 & $0.70-0.71$ & 0.71 & 2 \\
\hline $\mathrm{m} 1$ & $1.02-1.11$ & 1.07 & 2 & $0.72-0.80$ & 0.76 & 2 \\
\hline $\mathrm{m} 2$ & $0.93-1.07$ & 1.00 & 6 & $0.71-0.87$ & 0.76 & 5 \\
\hline $\mathrm{m} 3$ & - & 0.82 & 1 & - & 0.68 & 1 \\
\hline \multicolumn{7}{|c|}{ Strelac-2 } \\
\hline $\mathrm{m} 3$ & - & 0.95 & 1 & - & 0.78 & 1 \\
\hline
\end{tabular}

many specimens and many have a weak posterior spur of the paracone. The sinus is directed forwards. The M1 has three roots. M2: The labial branch of the anteroloph is long, but the lingual branch is a low and short, cingulum. The single transverse protolophule and the metalophule insert on the protocone and hypocone respectively. The long mesoloph is poorly developed in some Raljin-B specimens; it reaches the labial edge of the occlusal surface in others. The long posteroloph reaches the base of the metacone. The sinus is directed forwards. The M2 has three roots.

M3: The dental pattern of the very small M3 is remarkably complete in most specimens, but strongly reduced in the two specimens from Raljin-B. The anteroloph tends to fuse with the transverse anterior protolophule. The long mesoloph, the metalophule and the posteroloph are all preserved. The two M3 from Strelac-3 have a neo-entoloph (with arrow in Fig. 1c), but the sinus still separates the protocone from the hypocone. The dental pattern of the only M3 from Valniš is more irregular, because the lingual parts of the mesoloph and metalophule are fused. The two Raljin-B specimens have a well-developed anteroloph, protocone and paracone. Hypocone and metacone cannot be distinguished in the posteroloph surrounding the central basin. Within this basin low and short remnants of lophs are barely visible.

$\mathbf{m 1}$ : The anteroconid of the $\mathrm{m} 1$ is situated close to the protoconid and metaconid. In some specimens, it is a tiny round cusp, but in others it is developed as a low transverse cingulum. The protoconid, metalophulid and the metaconid form a v-shaped ridge. The long mesolophid is oblique and directed antero-lingually. The hypolophulid inserts on the hypoconid in one of the two specimens from Strelac-3, in all the others it inserts on the oblique ectolophid in front of the hypoconid. The posterolophid is long. A weak hypoconulid is just behind the hypoconid, the associated posterior sulcus is well developed in some $\mathrm{ml}$, but shallow or almost absent in others. The $\mathrm{m} 1$ has two roots.

m2: The lingual branch of the low anterolophid is longer than the labial branch. The short transverse metalophulid 1 and hypolophulid insert in front of the protoconid and hypoconid. The lengths of the posterior arm of the protoconid and the mesolophid show much individual variation: among the five $\mathrm{m} 2$ from Valniš four have a metalophulid 2 that is formed by the posterior arm of the protoconid, while their mesolophid is long (Fig. 2b). One of the four complete specimens from Raljin-B shows the same. In the fifth Valniš $\mathrm{m} 2$ the posterior arm of the protoconid is short and ends free in the mesosinusid, while the mesolophid is long. Among the six $\mathrm{m} 2$ from Strelac-3 one has the posterior arm of the protoconid extended by the lingual part of the mesolophid, in another the posterior arm of the protoconid is long while there are only irregular remnants of the mesolophid preserved, in two other $\mathrm{m} 2$ the long posterior arm of the protoconid reaches the lingual edge of the occlusal surface, while the mesolophid is short. The fifth $\mathrm{m} 2$ is aberrant, because its ectolophid is not connected to the protoconid as it is in all other 
$\mathrm{m} 2$ (Fig. 2k). In this specimen, the posterior arm of the protoconid and the mesolophid are both long. The posterolophid of all $\mathrm{m} 2$ is long and reaches the base of the entoconid.

m3: The lingual and labial branches of the anterolophid are about equally long in the $\mathrm{m} 3$. The short metalophulid 1 and the hypolophulid insert in front of the protoconid and hypoconid. The posterior arm of the protoconid is long and may reach the lingual edge of the occlusal surface. In one specimen from Valniš this ridge forms a metalophulid 2. The mesolophid is short or absent. The entoconid is incorporated into the posterolophid in most specimens. The posterior spur of the metaconid and the posterolophid form an entolophid which may be interrupted by a notch in front of the entoconid.

\section{Discussion and conclusions}

The Heosminthus primiveris specimens from Valniš and Strelac-3 show minor differences in morphology. The mesoloph of the M1 is on average longer in the specimens from Strelac-3 while the anteroloph is weaker. The number of M2 and M3 is too small to establish whether or not the differences in morphology are consistent. The anteroconid of the two $\mathrm{m} 1$ from Strelac-3 is a small round cusp, while it is a low ridge in five out of the seven $\mathrm{m} 1$ from Valniš. The posterior arm of the protoconid is strong and the mesolophid may be absent in the $\mathrm{m} 2$ from either locality.

Heosminthus is a common constituent of the late Eocene (see Li et al. 2016a, 2016b) and Early Oligocene rodent assemblages of China and Mongolia (Wang 1985; Daxner-Höck et al. 2014; Li et al. 2016a, 2016b), but was so far not known from Europe. Heosminthus was described as well from the late Eocene (?) of Süngülü (Lesser Caucasus; de Bruijn et al. 2003), these specimens resemble $H$. primiveris close and could be well included in this species.

The presence of Heosminthus in Serbia once again demonstrates that the Paleogene mammal assemblages from the Serbo-Macedonian high contain a large number of genera of Asian origin (Heissig 1979; Nikolov and Heissig 1985; de Bruijn et al. 2018; Marković et al. in press). The early Oligocene immigration of Heosminthus apparently never reached central and southwestern Europe, where the first dipodid, Plesiosminthus, arrived during the late Oligocene (MP27, see Freudenthal and Martín-Suárez 2017). In this context, it is of interest that the first record of Plesiosminthus in Serbia is from the latest Oligocene locality Paragovo (Marković, pers. comm.). This occurrence may well document the same westward migration of Plesiosminthus that reached central and southwestern Europe.

Heosminthus is the first representative of the Asian family Dipodidae that reached the Serbo-Macedonian high (S. E. Europe) where it is so far known from the early Oligocene only. In contrast to Plesiosminthus, which represents a second late
Oligocene westward migration of the family, Heosminthus seems not to have reached central and south western Europe. The presence of the species Heosminthus primiveris in the early Oligocene rodent assemblages from south east Serbia shows that the Dinarides Land (Popov et al. 2002; Rögl et al. 2004) was populated by a selection of rodent species of Asian origin during the Paleogene. This land mass was apparently large enough to allow subsequent endemic evolution of a diverse rodent fauna (de Bruijn et al. in press).

Acknowledgements We thank the director of the Natural History Museum in Belgrade for allowing us to use the museum Lada Niva during the field work. The hospitality and care of the owner and staff of hotel Nina in Babušnica contributed essentially to our success and living conditions. Mile Ilić allowed us to use the premises of the old mill in Ljuberadja. The dedicated work in the field and laboratory by Milos Milivojević (Natural History Museum in Belgrade) was indispensable.

We gratefully acknowledge the advice of, and discussions on the taxonomy of the Dipodidae with Gudrun Höck-Daxner. The reviewers Matthijs Freudenthal and Gudrun Höck-Daxner are thanked for their expert advice and improvements. We thank Tilly Bouten (Utrecht University) for her assistance at the table SEM. We are grateful to the "Hans de Bruijn Foundation" for supporting the fieldwork financially. Last but not least, we thank Jes de Bruijn-Dudok van Heel for her lunches, teas and coffees in the field.

\section{Compliance with ethical standards}

Conflict of interest The authors declare that they have no conflict of interest.

Open Access This article is distributed under the terms of the Creative Commons Attribution 4.0 International License (http:// creativecommons.org/licenses/by/4.0/), which permits unrestricted use, distribution, and reproduction in any medium, provided you give appropriate credit to the original author(s) and the source, provide a link to the Creative Commons license, and indicate if changes were made.

\section{References}

Bohlin, B. (1946). The fossil mammals from the tertiary deposit of TabenBuluk, western Kansu. Part 2: Simplicidentata, Carnivora, Artiodactyla and primates. Palaeontologia Sinica, new series $C$, $8 B, 1-259$

Bruijn, H. de, Ünay, E., Saraç, G., \& Yilmaz, A. (2003). A rodent assemblage from the Eo/Oligocene boundary interval near Süngülü, Lesser Caucasus, Turkey. In N. López-Martínez, P. PeláezCampomanes, \& M. Hernández Fernández (Eds.), En torno a Fósiles de Mamíferos: Datación, Evolución y Paleoambiente. Coloquios de Paleontología, Volumen Extraordinario no 1. En honor al dr. Remmert Daams (pp. 47-76).

Bruijn, H. de, Marković, Z., Wessels, W., Milivojević, M., \& Weerd, A. A. van de (2018). Rodent faunas from the Paleogene of south-east Serbia. Palaeobiodiversity and Palaeoenvironments., 98(3), 441458. https://doi.org/10.1007/s12549-017-0305-0.

Bruijn, H. de, Marković, Z., Wessels, W., \& Weerd, A. A.van de (in press). Pappocricetodontinae (Rodentia, Muroidea) from the Paleogene of south-east Serbia. Palaeobiodiversity and Palaeoenvironments. https://doi.org/10.1007/s12549-018-0343-2. 
Dawson, M. R. (2003). Paleogene rodents of Eurasia. In J. W. F. Reumer $\&$ W. Wessels (Eds.), Distribution and migration of tertiary mammals in Eurasia. A volume in honour of Hans de Bruijn. Deinsea (Vol. 10, pp. 97-127).

Daxner-Höck, G., Badamgarav, D., \& Maridet, O. (2014). Dipodidae (Rodentia, Mammalia) from the Oligocene and Early Miocene of Mongolia. Annalen des Naturhistorischen Museums in Wien. Serie A, 116, 131-214.

Fischer, G. (1817). Adversaria zoologica. Mémoires de la Société Impériale des Naturalistes de Moscou., 5, 357-472.

Freudenthal, M., \& Martín-Suárez, E. (2017). A revision of European Plesiosminthus (Rodentia, Dipodidae), and new material from the upper Oligocene of Teruel (Spain). Palaeontologia Electronica, 20, 2 41A, 1-25.

Gomes Rodrigues, H., Charles, C., Marivaux, L., Vianey-Liaud, M., \& Viriota, L. (2011). Evolutionary and developmental dynamics of the dentition in Muroidea and Dipodoidea (Rodentia, Mammalia). Evolution \& Development, 13(4), 361-369. https://doi.org/10. 1111/j.1525-142X.2011.00491.

Heissig, K. (1979). Die hypothetische Rolle Südosteuropas bei den Säugetierwanderungen im Eozän und Oligozän. Neues Jahrbuch für Geologie und Paläontologie, Monatshefte, 2, 83-96.

Huang, X.-S. (1992). Zapodidae (Rodentia, Mammalia) from the middle Oligocene of Ulantatal, Nei Mongol. Vertebrata PalAsiatica, 30, 249-286.

Hugueney, M., \& Vianey-Liaud, M. (1980). Les Dipodidae (Mammalia, Rodentia) d'Europe Occidentale au Paleogène et au Neogène inferieur: Origine et evolution. Palaeovertebrata, Mémoire Jubilaire R. Lavocat, 9, 303-342.

Li, Q., Meng, J., \& Wang, Y. (2016a). New Cricetid rodents from strata near the Eocene-Oligocene boundary in Erden Obo section (Nei Mongol, China). PLoS One, 11(5), e0156233. https://doi.org/10. 1371/journal.pone.0156233.

Li, Q., Gong, Y.-X., \& Wang, Y. (2016b). New dipodid rodents from the late Eocene of Erden Obo (Nei Mongol, China). Historical Biology, 29(5), 692-703.

Lopatin, A. V. (1999). Early Miocene Zapodidae (Rodentia, Mammalia) from the Aral Formation of the Altynshokysu locality (North Aral region). Paleontological Journal, 33(4), 429-438.

Lopatin, A. V. (2004). Early Miocene small mammals from the North Aral Region (Kazakhstan) with special reference to their biostratigraphic significance. Paleontological Journal, 38 (2), 211-219.

Lopatin, A. V., \& Zazhigin, V. S. (2000). The history of Dipodidae (Rodentia, Mammalia) in the Miocene of Asia: 2. Zapodidae. Paleontological Journal, 34(4), 449-454.

Marković, Z., Wessels, W., Weerd, A. A. van de, \& Bruijn, H. de (2018). On a new diatomyid (Rodentia, Mammalia) from the Paleogene of south-east Serbia, the first record of the family in Europe. Palaeobiodiversity and Palaeoenvironments, 98, 459-469. https:// doi.org/10.1007/s12549-017-0301-4.

Marković, A., Wessels, W., Weerd, A. A. van de, \& Bruijn, H. de (in press). Pseudocricetodontinae (Mammalia, Rodentia) from the Paleogene of south-east Serbia. Palaeobiodiversity and Palaeoenvironments. https://doi.org/10.1007/s12549-019-00373-8.
Nikolov, I., \& Heissig, K. (1985). Fossile Säugetiere aus dem Obereozän und Unteroligozän Bulgariens und ihre Bedeutung für die Palaeogeographie. Mitteilungen der Bayerischen Staatssammlung für Paläontologie und historische Geologie, 25, 61-79.

Pisano, J., Condamine, F.L., Lebedev, V., Bannikova, A., Quéré, J.-P., , Shenbrot, G.I., Pages, M. and Michaux, J. R. (2015). Out of Himalaya: the impact of past Asian environmental changes on the evolutionary and biogeographical history of Dipodoidea (Rodentia). Journal of Biogeography, 42, 856-870.

Popov, S. V., Akhmetiev, M. A., Bugrova, E. M., Lopatin, A. V., Amitrov, O. V., Andreyeva-Grigorovich, A. S., Zaporozhets, N. I., Zherikhin, V. V., Krasheninnikov, V. A., Nikolaeva, I. A., Sytchevskaya, E. K., \& Shcherba, I. G. (2002). Biogeography of the northern Peri-Tethys from the late Eocene to the early Miocene. Part 2 Early Oligocene. Paleontological Journal, 36, suppl 3, 185-259.

Rögl, F., Rozanov, A. Y., Steiniger, F. F., Shcherba, I. G., \& Kovac, M. (Eds.) (2004). Lithological-Paleogeographic maps of Paratethys, 10 maps, Late Eocene to Pliocene. Courier Forschungsinstitut Senckenberg 250, 1-46.

Schaub, S. (1930). Fossile Sicistinae. Eclogae geologicae Helvetiae, 23(2), 616-636.

Tong, Y. (1997). Middle Eocene small mammals from Liguanqiao basin of Henan province, Central China. Palaeontologica Sinica, New Series $C, 18,1-255$.

Viret, J. (1926). Nouvelles observations relatives à la faune de rongeurs de St Gérand·le·Puy. Comptes rendus Académie des Sciences, Paris, 183, 71-72.

Wang, B.-Y. (1985). Zapodidae (Rodentia, Mammalia) from the lower Oligocene of Qujing, Yunnan, China. Mainzer Geowissenschaftliche Mitteilungen, 14, 345-367.

Wang, B., \& Dawson, M. R. (1994). A primitive cricetid (Mammalia, Rodentia) from the middle Eocene of Jiangsu province, China. Annals of Carnegie Museum, 63, 239-256.

Wang, B.-Y., \& Qiu, Z.-X. (2000). Dipodidae (Rodentia, Mammalia) from the lower member of Xianshuihe Formation in Lanzhou Basin, Gansu, China. Vertebrata PalAsiatica, 38(1), 10-35 [in Chinese with English summary].

Weerd, A. A. van de, Bruijn, H. de, Marković, Z., \& Wessels, W. (2018). Paracricetodontinae (Mammalia, Rodentia) from the late Eocene and early Oligocene of S. E. Serbia. Palaeobiodiversity and Palaeoenvironments, 98, 489-508. https://doi.org/10.1007/s12549017-0317-9.

Wessels, W., Weerd, A. A. van de, Bruijn, H. de, \& Marković, Z. (2018). New Melissiodontinae (Mammalia, Rodentia) from the Paleogene of south-east Serbia. Palaeobiodiversity and Palaeoenvironments, 98, 471-487. https://doi.org/10.1007/s12549-017-0311-2.

Publisher's note Springer Nature remains neutral with regard to jurisdictional claims in published maps and institutional affiliations. 